\title{
Cationic Nanostructures against Foodborne Pathogens
}

\author{
Letícia Dias de Melo Carrasco ${ }^{1,2}$, Ronaldo Bertolucci Jr. ${ }^{1}$, Rodrigo T. Ribeiro ${ }^{1}$, \\ Jorge L. M. Sampaio ${ }^{2}$ and Ana M. Carmona-Ribeiro ${ }^{1,2 *}$
}

${ }^{1}$ Laboratório de Biocolóides, Departamento de Bioquímica, Instituto de Química, Universidade de São Paulo, São Paulo, Brazil, ${ }^{2}$ Laboratório de Microbiologia, Departamento de Análises Clínicas e Toxicológicas, Faculdade de Ciências Farmacêuticas, Universidade de São Paulo, São Paulo, Brazil

Keywords: gramicidin D, dioctadecyldimethylammonium bromide, polydiallyldimethyl ammonium chloride, polymethylmethacrylate, Escherichia coli, Staphylococcus aureus, Salmonella enterica, Listeria monocytogenes

\section{OPEN ACCESS}

Edited by:

Spiros Paramithiotis,

Agricultural University of Athens,

Greece

Reviewed by:

Carmen Losasso,

Istituto Zooprofilattico Sperimentale

delle Venezie, Italy

Yalong Bai,

Shanghai Academy of Agricultural

Sciences, China

*Correspondence:

Ana M. Carmona-Ribeiro

amcr@usp.br

Specialty section:

This article was submitted to

Food Microbiology,

a section of the journal

Frontiers in Microbiology

Received: 16 August 2016 Accepted: 27 October 2016

Published: 09 November 2016

Citation

Carrasco LD, Bertolucci R, Jr., Ribeiro

RT, Sampaio JLM and

Carmona-Ribeiro AM (2016) Cationic

Nanostructures against Foodborne

Pathogens. Front. Microbiol. 7:1804.

doi: 10.3389/fmicb.2016.01804
In food microbiology, novel strategies to fight foodborne pathogens are certainly welcome. In this data report, cationic nanostructures built from combinations of nanoparticles, antimicrobial peptide and cationic lipid are evaluated against important foodborne pathogens such as Escherichia coli, Salmonella enterica subsp. serovar Typhymurium, Staphylococcus aureus and Listeria monocytogenes.

The cationic lipid dioctadecyldimethylammonium bromide (DODAB), the antimicrobial peptide gramicidin D (Gr), the antimicrobial cationic polymer poly (diallyldimethylammonium chloride) (PDDA) and the biocompatible polymer poly (methyl methacrylate) (PMMA) can be combined to yield a variety of antimicrobial cationic nanostructures as previously described by our group (Carmona Ribeiro and Chaimovich, 1983; Martins et al., 1997; Lincopan et al., 2003, 2005; Pereira et al., 2008; Melo et al., 2010, 2011; Carvalho et al., 2012; Naves et al., 2013; Ragioto et al., 2014; Carrasco et al., 2015; Sanches et al., 2015). However, these nanostructures were not specifically evaluated against foodborne pathogens before. This data report aims at filling up this gap.

The cationic lipid (DODAB) and the cationic polymer PDDA bear quaternary antimicrobial nitrogens and form a variety of cationic nanostructures as the closed or open bilayers; the hybrid polymeric nanoparticles NPs and the DODAB/Gr combinations. Schemes, physical properties and antimicrobial activity for the cationic assemblies against the foodborne pathogens are on the data set (https://www.researchgate.net/publication/ 308140571_September_15_2016_data_set_on_cationic_assemblies_against_food_pathogens.)

DODAB, Gr, PDDA, PMMA, ethanol, 2,2,2-trifluoroethanol (TFE) and $\mathrm{NaCl}$ were from SigmaAldrich (St. Louis, MO, USA). DODAB LV were obtained by hydrating and vortexing the DODAB powder in $1 \mathrm{mM} \mathrm{NaCl}$ aqueous solution, at $60^{\circ} \mathrm{C}$ at $2 \mathrm{mM}$ DODAB (Carmona Ribeiro and Chaimovich, 1983). For obtaining the DODAB BF, LV were ultrasonically disrupted with a macrotip $\left(85 \mathrm{~W} / 15 \mathrm{~min} / 70^{\circ} \mathrm{C}\right)$ before centrifuging $\left(10,000 \mathrm{rpm} / 60 \mathrm{~min} / 4^{\circ} \mathrm{C}\right)$ and collecting the supernatant (Carmona-Ribeiro, 2006). DODAB analysis was via microtitration of its bromide counterion (Schales and Schales, 1941).

A Gr stock solution (6.4 mM Gr) in TFE was added to previously prepared LV or BF at a 1:10 Gr:DODAB molar ratio. DODAB/Gr dispersions were prepared from DODAB LV incubated for $1 \mathrm{~h} / 60^{\circ} \mathrm{C}$ with $\mathrm{Gr}$ (Ragioto et al., 2014). DODAB LV/ Gr sonicated with macrotip $\left(85 \mathrm{~W} / 15 \mathrm{~min} / 70^{\circ} \mathrm{C}\right)$ and centrifuged $\left(10,000 \mathrm{rpm} / 60 \mathrm{~min} / 4^{\circ} \mathrm{C}\right)$ yield the $\mathrm{DODAB} \mathrm{BF} / \mathrm{Gr}$.

Abbreviations: ATCC, American Type Culture Collection; BF, Bilayer fragments; CFU, Colony forming unit; CTAB, cetyltrimethyl ammonium bromide; DLS, Dynamic light scattering; DODAB, Dioctadecyldimethylammonium bromide; Dz, zeta-average diameter; Gr, Gramicidin D; LV, Large vesicles; MBC, minimal bactericidal concentration; MIC, Minimal inhibitory concentration; MHA, Mueller-Hinton agar; NP, nanoparticle; P, Polydispersity; PDDA, poly (diallyldimethylammonium) chloride; PMMA, poly (methylmethacrylate); TFE, 2,2,2-trifluoroethanol (TFE); $\zeta$, zetapotencial. 
PMMA/DODAB and PMMA/PDDA NPs were obtained as previously described (Naves et al., 2013; Sanches et al., 2015).

All nanostructures were characterized for sizing (zetaaverage diameter or $\mathrm{Dz}$ ), zeta-potential $(\zeta)$ and polydispersity (P) using a Zeta Plus-Zeta Potential Analyzer (Brookhaven Instruments Corporation, Holtsville, NY, USA) equipped with a laser $(677 \mathrm{~nm})$ for DLS with measurements at $90^{\circ}$ (Grabowski and Morrison, 1983). $\zeta$ values were calculated from the electrophoretic mobility $(\mu)$ and Smoluchovski equation $(\zeta=$ $\mu \eta / \varepsilon$, where $\eta$ is the medium viscosity and $\varepsilon$, the dielectric constant).

Food pathogens from American Type Culture Collection (ATCC) (Manassas, VA, USA) were S. aureus ATCC 29213, E. coli ATCC 25922, L. monocytogenes ATCC 19111 and S. enterica ATCC 14028. After reactivation from frozen stocks in MHA, strains' cultures incubated in MHA $\left(37^{\circ} \mathrm{C} / 18-48 \mathrm{~h}\right.$ depending on the pathogen) had some colonies transferred to a $1 \mathrm{mM}$ $\mathrm{NaCl}$ solution and turbidity was adjusted to $0.5 \mathrm{McF}$ arland (Chapin and Lauderdale, 2007). After $1 \mathrm{~h}$ interaction between nanostructures and bacteria in $1 \mathrm{mM} \mathrm{NaCl}$ over a range of DODAB, Gr or PDDA concentrations in the nanostructures, mixtures were diluted up to 100,000 before plating $0.1 \mathrm{~mL}$ onto MHA surface in triplicate. Controls were bacteria only in $1 \mathrm{mM}$ $\mathrm{NaCl}$ (plated after $1 \mathrm{~h}$ ). After incubation $\left(37^{\circ} \mathrm{C} / 24-48 \mathrm{~h}\right)$ and $\mathrm{CFU} / \mathrm{mL}$ counting, $\mathrm{MBC}$ is the lowest concentration yielding the minimal CFU counting.

Gr insertion in DODAB LV bilayer reduced Dz and increased the positive $\zeta$-potential. Gr tryptophans anchoring the peptide at the bilayer-water interface sterically stabilized DODAB/Gr. Disrupting DODAB LV/Gr led to cationic bilayers with $\mathrm{Gr}$ molecules inserted as dimeric channels so that the packing of the cationic lipids in the bilayer and the $\zeta$-potentials increased. Other assemblies also tested in this work against the food pathogens had DODAB embedded in PMMA or PDDA making an outer layer (shell) in core-shell PMMA/PDDA positively charged NPs.

DODAB not only carried Gr but also displayed antimicrobial activity and reduced the $\mathrm{MBC}$ values against most strains tested. Table 1 shows MBCs in $\mathrm{mM}$ or $\mathrm{mg} / \mathrm{mL}$ and the total reduction in viability caused by the antimicrobials. The $\mathrm{Gr}$ peptide was effective against the two Gram-positive bacteria.
DODAB BF or LV affected all bacteria tested with exception of $S$. enterica. Mostly DODAB BF was more efficacious against the bacteria than LV. The Gr peptide in DODAB BF reduced $\mathrm{MBC}$ values against three bacteria strains (lines 2 and 3, Table 1). This effect was important due to the toxicity of the cationic lipid and the antimicrobial peptide. S. enterica was the most refractory strain to the cationic agents alone or in combinations with exception of PDDA or PMMA/PDDA NPs (Table 1). In particular, the PMMA/PDDA NPs (last line on Table 1) were very efficient against $S$. enterica. DODAB in the PMMA/DODAB NPs displayed a reduced antimicrobial activity whereas PDDA exposure as an outer shell on the PMMA/PDDA NPs increased the antimicrobial activity (Table 1). The log of viability reduction at $\mathrm{MBC}$ against $S$. enterica of DODAB $\mathrm{BF} / \mathrm{Gr}$ and DODAB LV/Gr was slightly lower than the one for DODAB BF and DODAB LV possibly due to the bulky nature of $\mathrm{Gr}$ tryptophans located at the bilayer/water interface, which prevented the close electrostatic attraction between the cationic moieties of the nanostructures and the anionic moieties of the bacteria.

Antimicrobial activity can be determined as inhibition of growth or minimal inhibitory concentration (MIC) or as cells survival in $\log (\mathrm{CFU} / \mathrm{mL})(\mathrm{MBC})$. Here $\mathrm{MBC}$ determinations and reduction in $\log (\mathrm{CFU} / \mathrm{mL})$ at $\mathrm{MBC}$ properly quantified the antimicrobial effect of the cationic nanostructures (Table 1). As concentrations required for inhibition are smaller than those for death, the consistency of the results can be checked: MIC for $\mathrm{Gr}$ against $S$. aureus was $2.5 \mu \mathrm{M}$. (Wang et al., 2012) and MBC for $\mathrm{Gr}$ against $S$. aureus was $10 \mu \mathrm{M}$ (Table 1), a value consistently higher than the MIC value. Gr displayed a high toxicity against mammalian (Sorochkina et al., 2012; Wang et al., 2012) and eukaryotic cells such as S. cerevisae seen as $50 \%$ of cell viability at $1 \mu \mathrm{M}$ Gr (Ragioto et al., 2014). However, in formulations with DODAB, Gr toxicity decreased against $S$. cerevisae (Ragioto et al., 2014). Reductions in MBC for DODAB in the combinations with $\mathrm{Gr}$ mean reduction in $\mathrm{Gr}$ doses since $\mathrm{Gr}$ concentration is always $10 \%$ of the DODAB concentration in each combination. Against mammalian cells, $0.5 \mathrm{mM}$ DODAB killed $50 \%$ of fibroblasts in culture (Carmona-Ribeiro et al., 1997). Despite the DODAB relative toxicity in vitro, there were instances of good activity

TABLE 1 | MBC (mM; mg/mL) and log of viability reduction at MBC for cationic nanostructures against food pathogens.

\begin{tabular}{|c|c|c|c|c|}
\hline Assembly & \multicolumn{4}{|c|}{ MBC in $\mathrm{mM} ; \mathrm{mg} / \mathrm{mL} /$ Reduction in $\log (\mathrm{CFU} / \mathrm{mL})$} \\
\hline DODAB BF & $0.063 ; 0.039 / 7.6$ & $0.500 ; 0.316 / 1.3$ & $0.063 ; 0.039 / 3.4$ & $0.125 ; 0.079 / 7.8$ \\
\hline DODAB BF/Gr & $0.031 ; 0.019 / 7.5$ & $0.250 ; 0.158 / 0.9$ & $0.015 ; 0.010 / 3.8$ & $0.125 ; 0.079 / 8.0$ \\
\hline DODAB LV & $0.015 ; 0.010 / 4.5$ & $0.500 ; 0.316 / 0.7$ & $0.015 ; 0.010 / 2.9$ & $0.250 ; 0.158 / 5.7$ \\
\hline PMMA/DODAB & $-----; 2.500 / 2.2$ & $-----; 1.250 / 0.1$ & $-----; 5.000 / 3.1$ & $-----;$ 5.000/ 1.5 \\
\hline PDDA & $------; 0.005 / 7.5$ & $------; 4.810 / 3.3$ & $-----; 0.010 / 5.8$ & $-----; 0.048 / 0.5$ \\
\hline PMMA/PDDA & -----; 0.009/ 7.5 & $------; 0.940 / 6.9$ & $-----; 0.940 / 7.1$ & $-----; 0.940 / 5.1$ \\
\hline
\end{tabular}

For DODAB/Gr combinations, the molar ratio is $[\mathrm{Gr}]=0.1[\mathrm{DODAB}]$. 
for DODAB formulations in vivo. For example, DODAB could be used as an effective immunoadjuvant in combination with peptides or proteins for vaccines (Tsuruta et al., 1997; CarmonaRibeiro, 2014) or could incorporate amphotericin B against systemic candidiasis in mice inducing about $100 \%$ of mice survival after treatment in absence of nephrotoxicity (Lincopan et al., 2003, 2005).

DODAB and DODAB/Gr interacted with bacteria driven by the electrostatic attraction and their mechanism of action involved lysis of the bacteria with leakage of intracellular compounds to the external medium and distortions in cell morphology (Martins et al., 1997; Ragioto et al., 2014). Gr required insertion in the bacterial cell membrane in order to act as a channel for permeation of cations across the membrane; this disturbed the ionic balance and ultimately led to the observed Gr antibiotic activity (Harold and Baarda, 1967; Clement and Gould, 1981; Hamada et al., 2010). Thus, for the DODAB/Gr combinations, the mechanism involved would include both the lytic aspects of DODAB interaction with the bacteria and the Gr effects on membrane function and selectivity in the transport of ions and nutrients and ion distribution in the cell.

DODAB could be incorporated in a polymeric biocompatible network of PMMA (Pereira et al., 2008) but displayed limited antimicrobial activity therein (Table $\mathbf{1}$ ) in contrast to the one of the more mobile CTAB surfactant which readily diffused across the polymeric PMMA network, reached attached or free bacteria and displayed good antimicrobial activity (Melo et al., 2011). Therefore, the good miscibility of DODAB lipid in the polymeric network of PDDA hampered DODAB diffusion to the outer medium where DODAB would act against the bacteria.

L. monocytogenes was very sensitive to the cationic lipid DODAB and the antimicrobial neutral peptide Gr (Table 1). Lysozyme and cationic peptides targeting the L. monocytogenes cell wall to promoted bacterial lysis. The introduction of specific modifications in components of the cell envelope as a strategy developed by bacteria rendered them undetectable to both immune recognition and to the bacteriolytic activity of host defense enzymes such as lysozyme and cationic antimicrobial peptides (Davis and Weiser, 2011; Carvalho et al., 2014). It seems that $L$. monocytogenes did not develop yet any mechanism against DODAB or $\mathrm{Gr}$ so that these might be advantageously employed in anti- $L$. monocytogenes coatings. On the other hand, the cationic antimicrobial polymer PDDA, similarly to cationic peptides did not affect this pathogen (Table 1).This is understandable from the already disclosed $L$. monocytogenes mechanisms to fight the cationic antimicrobial peptides. Curiously, the spherical assembly of PDDA as an outer shell of a PMMA/PDDA NP exhibits a reduction of 5 logs against L. monocytogenes (Table 1), suggesting that this bacterium is not prepared against this cationic NP and this also may become an asset in the fight against the pathogen.
Alternating layers of branched polyethylenimine and styrene maleic anhydride copolymer were applied onto the surface of polypropylene yielding coatings with low surface energy and enhanced antimicrobial character due to the presence of both cationic and N-halamine moieties; the coating inactivated $L$. monocytogenes by $\sim 3$ logarithmic cycles whereas in the form of $\mathrm{N}$-halamines there was more than 5 logarithmic cycles in the viable cells counting (Bastarrachea and Goddard, 2015). In this respect, it seemed advantageous to introduce PMMA/PDDA NPs as efficient assemblies to reduce $L$. monocytogenes cell viability by 5 logarithmic cycles (Table $\mathbf{1}$ ).

S. enterica is one of the most important foodborne pathogens, leading to millions of cases of enteric diseases, thousands of hospitalizations and deaths worldwide each year (Hur et al., 2011). These bacteria were not sensitive to the majority of the cationic assemblies tested (Table $\mathbf{1}$ ) with exception of PDDA (3 logs reduction in viability) or PMMA/PDDA (5 logs reduction in viability) (Table 1). Although the antibacterial effect of antimicrobial peptides and polymers was mediated by membrane disruption with leakage of intracellular compounds (Carrasco et al., 2015), it was not clear how they reached the bacterial cytoplasmic membrane, crossing barriers such as the external membrane of Gram-negative bacteria and the cell wall of Grampositive bacteria. Possibly the peptide or polymer first targets the outer cell wall and then undergoes a self-promoted uptake (Hancock, 1997; Yaron et al., 2003). In this respect, our results suggested that only PDDA and PMMA/PDDA NPs targeted the cytoplasmic membrane of $S$. enterica causing lysis and death. In particular, the activity of the NPs was higher than the one of the free polymer (Table 1), suggesting that they were more effective in inducing membrane disruption than the free polymer.

\section{AUTHOR CONTRIBUTIONS}

LC and RB performed all the experiments, analyzed the results and helped writing the manuscript; RR provided technical assistance and helped discussing the manuscript; JS provided all bacterial strains and important advice for growing them; AC designed the study, interpreted the results and wrote the manuscript.

\section{FUNDING}

Financial support was from Conselho Nacional de Desenvolvimento Científico e Tecnológico (CNPq 302352/2014-7).

\section{ACKNOWLEDGMENTS}

LC and RB were recipients of fellowships from FAPESP (2012/24534-1) and Programa Unificado de Bolsas (Pro-Reitoria de Graduação- Universidade de São Paulo), respectively. AC thanks CNPq for a 1A research fellowship (302352/2014-7). 


\section{REFERENCES}

Bastarrachea, L. J., and Goddard, J. M. (2015). Antimicrobial coatings with dual cationic and N-halamine character: characterization and biocidal efficacy. J. Agric. Food Chem. 63, 4243-4251. doi: 10.1021/acs.jafc.5b00445

Carmona-Ribeiro, A. M. (2006). Lipid bilayer fragments and disks in drug delivery. Curr. Med. Chem. 13, 1359-1370. doi: 10.2174/092986706776872925

Carmona-Ribeiro, A. M. (2014). Cationic Nanostructures for Vaccines, Immune Response Activation. InTech. doi: 10.5772/57543. Available online at: http://www.intechopen.com/books/immune-response-activation/cationicnanostructures-for-vaccines

Carmona Ribeiro, A. M., and Chaimovich, H. (1983). Preparation and characterization of large dioctadecyldimethylammonium chloride lipossomes and comparison with small sonicated vesicles. Biochim. Biophys. Acta 733, 172-179. doi: 10.1016/0005-2736(83)90103-7

Carmona-Ribeiro, A. M., Ortis, F., Schumacher, R. I., and Armelin, M. C. S. (1997). Interactions between cationic vesicles and cultured mammalian cells. Langmuir 13, 2215-2218. doi: 10.1021/la960759h

Carrasco, L. D. M., Sampaio, J. L., and Carmona-Ribeiro, A. M. (2015). Supramolecular cationic assemblies against multidrug-resistant microorganisms: activity and mechanism of action. Int. J. Mol. Sci. 16, 6337-6352. doi: 10.3390/ijms16036337

Carvalho, C. A., Olivares-Ortega, C., Soto-Arriaza, M. A., and Carmona-Ribeiro, A. M. (2012). Interaction of gramicidin with DPPC/DODAB bilayer fragments. Biochim. Biophys Acta. 1818, 3064-3071. doi: 10.1016/j.bbamem.2012.08.008

Carvalho, F., Sousa, S., and Cabanes, D. (2014). How Listeria monocytogenes organizes its surface for virulence. Front. Cell. Infect. Microbiol. 4:48. doi: 10.3389/fcimb. 2014.00048

Chapin, K. C., and Lauderdale, T. (2007). "Reagents, stains, and media: bacteriology," in Manual of Clinical Microbiology, eds P. R. Murray, E. J. Baron, J. H. Jorgensen, M. L. Landry and M. A. Pfaller (Washington, DC: ASM Press), 334-364.

Clement, N. R., and Gould, J. M. (1981). Kinetics for development of gramicidininduced ion permeability in unilamellar phospholipid vesicles. Biochemistry 20, 1544-1548. doi: 10.1021/bi00509a021

Davis, K. M., and Weiser, J. N. (2011). Modifications to the peptidoglycan backbone help bacteria to establish infection. Infect. Immun. 79, 562-570. doi: 10.1128/IAI.00651-10

Grabowski, E., and Morrison, I. (1983). "Particle size distribution from analysis of quasielastic light scattering data," in Measurements of Suspended Particles by Quasielastic Light Scattering, ed B. Dahneke (New York, NY: WileyInterscience), 199-236.

Hamada, T., Matsunaga, S., Fujiwara, M., Fujita, K., Hirota, H., Schmucki, R., et al. (2010). Solution structure of polytheonamide B, a highly cytotoxic nonribosomal polypeptide from marine sponge. J. Am. Chem. Soc. 132, 12941-12945. doi: 10.1021/ja104616z

Hancock, R. E. W. (1997). Peptide antibiotics. Lancet 349, 418-422. doi: 10.1016/S0140-6736(97)80051-7

Harold, F. M., and Baarda, J. R. (1967). Gramicidin, valinomycin, and cation permeability of Streptococcus faecalis. J. Bacteriol. 94, 53-60.

Hur, J., Jawale, C., and Lee, J. H. (2011). Antimicrobial resistance of Salmonella isolated from food animals: a review. Food Res. Int. 45, 819-830. doi: 10.1016/j.foodres.2011.05.014

Lincopan, N., Mamizuka, E. M., and Carmona-Ribeiro, A. M. (2003). In vivo activity of a novel amphotericin B formulation with synthetic cationic bilayer fragments. J. Antimicrob. Chemother. 52, 412-418. doi: 10.1093/jac/dkg383
Lincopan, N., Mamizuka, E. M., and Carmona-Ribeiro, A. M. (2005). Low nephrotoxicity of an effective amphotericin B formulation with cationic bilayer fragments. J. Antimicrob. Chemother. 55, 727-734. doi: 10.1093/jac/ dki064

Martins, L. M. S., Mamizuka, E. M., and Carmona-Ribeiro, A. M. (1997). Cationic vesicles as bactericides. Langmuir 13, 5583-5587. doi: 10.1021/la970353k

Melo, L. D. M., Mamizuka, E. M., and Carmona-Ribeiro, A. M. (2010). Antimicrobial particles from cationic lipid and polyelectrolytes. Langmuir 26, 12300-12306. doi: 10.1021/la101500s

Melo, L. D. M., Palombo, R. R., Petri, D. F. S., Bruns, M., Pereira, E. M. A., and Carmona-Ribeiro, A. M. (2011). Structure-activity relationship for quaternary ammonium compounds hybridized with poly(methyl methacrylate). ACS Appl. Mater. Interfaces 3, 1933-1939. doi: 10.1021/am200150t

Naves, A. F., Palombo, R. R., Carrasco, L. D., and Carmona-Ribeiro, A. M. (2013). Antimicrobial particles from emulsion polymerization of methyl methacrylate in the presence of quaternary ammonium surfactants. Langmuir 29, 9677-9684. doi: $10.1021 / \mathrm{la} 401527 \mathrm{j}$

Pereira, E. M. A., Kosaka, P. M., Rosa, H., Vieira, D. B., Kawano, Y., Petri, D. F. S., et al. (2008). Hybrid materials from intermolecular associations between cationic lipid and polymers. J. Phys. Chem. B 112, 9301-9310. doi: 10.1021/jp801297t

Ragioto, D. A., Carrasco, L. D., and Carmona-Ribeiro, A. M. (2014). Novel gramicidin formulations in cationic lipid as broad-spectrum microbicidal agents. Int. J. Nanomed. 9, 3183-3192. doi: 10.2147/IJN.S65289

Sanches, L. M., Petri, D. F., de Melo Carrasco, L. D., and CarmonaRibeiro, A. M. (2015). The antimicrobial activity of free and immobilized poly (diallyldimethylammonium) chloride in nanoparticles of poly (methylmethacrylate). J. Nanobiotechnol. 13, 58. doi: 10.1186/s12951-015-0123-3

Schales, O., and Schales, S. S. (1941). A simple and accurate method for the determination of chloride in biological fluids. J. Biol. Chem. 140, 879-884.

Sorochkina, A. I., Plotnikov, E. Y., Rokitskaya, T. I., Kovalchuk, S. I., Kotova, E. A., Sychev, S. V., et al. (2012). N-terminally glutamate-substituted analogue of gramicidin A as a protonophore and selective mitochondrial uncoupler. PLoS ONE 7:41919. doi: 10.1371/journal.pone.0041919

Tsuruta, L. R., Quintilio, W., Costa, M. H. B., and Carmona-Ribeiro, A. M. (1997). Interactions between cationic liposomes and an antigenic protein: the physical chemistry of the immunoadjuvant action. J. Lipid Res. 38, 2003-2011.

Wang, F., Qin, L., Pace, C. J., Wong, P., Malonis, R., and Gao, J. (2012). Solubilized gramicidin A as potential systemic antibiotics. Chem. Bio. Chem. 13, 51-55. doi: 10.1002/cbic.201100671

Yaron, S., Rydlo, T., Shachar, D., and Mor, A. (2003). Activity of dermaseptin K4-S4 against foodborne pathogens. Peptides 24, 1815-1821. doi: 10.1016/j.peptides.2003.09.016

Conflict of Interest Statement: The authors declare that the research was conducted in the absence of any commercial or financial relationships that could be construed as a potential conflict of interest.

Copyright (c) 2016 Carrasco, Bertolucci, Ribeiro, Sampaio and Carmona-Ribeiro. This is an open-access article distributed under the terms of the Creative Commons Attribution License (CC BY). The use, distribution or reproduction in other forums is permitted, provided the original author(s) or licensor are credited and that the original publication in this journal is cited, in accordance with accepted academic practice. No use, distribution or reproduction is permitted which does not comply with these terms. 